\title{
THE VALUE OF PRE-OPERATIVE TESTING FOR COVID-19 IN UROLOGICAL PATIENTS
}

\author{
Vasileios Bonatsos ${ }^{1}, \mathrm{MD}, \mathrm{PhD}, \mathrm{MSc}$, Urology SpR and Asif Raza², MBChB, FRCS (Gen Surg), FRCS (Urol), \\ FEBU \\ ${ }^{1}$ London North West University Healthcare NHS Trust \\ 2 Honorary Associate Professor, Plymouth University Medical and Dental School, Honorary Senior \\ Lecturer, Imperial College, London, Consultant Urological Surgeon, London Northwest University \\ Healthcare NHS Trust
}

Corresponding author: Vasileios Bonatsos, Vasileios.bonatsos1@nhs.net and basilbon@gmail.com

Submitted: August 18, 2020. Accepted: September 14, 2020. Published: September 19, 2020.

\begin{abstract}
According to the World Health Organisation there have been 30,055,710 confirmed COVID-19 cases and 943,433 confirmed deaths across 216 countries globally. The availability of the complete SARS-CoV-2 genome relatively early in the epidemic has enabled the development of tests for the diagnosis of COVID19. There are two broad categories of SARS-CoV-2 diagnostic tests currently in use or development: (1) Real-time reverse transcriptase polymerase chain reaction (RT-PCR) tests and (2) serology tests. RT-PCR is considered the gold standard and preferred method of diagnosis of acute infection. There is, however, a plethora of laboratory-developed and commercial RT-PCR assays with different gene targets. We discuss the value of pre-operative testing for COVID-19 before urological surgery.
\end{abstract}

Keywords: COVID-19, PCR, Antibodies, Urology, Testing

\section{INTRODUCTION}

COVID-19 was declared a pandemic by the World Health Organization on March 11, 2020. ${ }^{1}$ This has led to unprecedented changes to the healthcare sector regardless of specialty with a significant impact on the provision of both emergency and elective surgical services. COVID-19 has affected both patients and NHS staff. Urological procedures can be aerosol-generating and patient's urine and stools may contain coronavirus which may increase the risk of COVID-19 transmission between patients and staff. ${ }^{2-4}$ Studies have shown operating room staff including doctors and nurses have subsequently been diagnosed with COVID-19 despite taking protective measures to prevent viral transmission during surgical procedures. ${ }^{5}$

The availability of the complete SARS-CoV-2 genome relatively early in the epidemic has enabled the development of 2 main tests to diagnose COVID-19 i.e. PCR and serological tests. ${ }^{6,7}$ As a result of this global pandemic Urologists have had to strike a balance between providing optimal and high-quality urological care whilst mitigating the risks of COVID-19 dispersal among patients and staff. ${ }^{5,8}$ Urological professional bodies have adopted a COVID-19 testing protocol as part of their pre-operative assessment protocols including a period of self-isolation ( see Table 1).

J Endolum Endourol Vol 3(3):e29-e34; September 19, 2020.

This article is distributed under the terms of the Creative Commons Attribution-Non Commercial 4.0 International License. CBonatsos and Raza. 


\section{DISCUSSION AND RECOMMENDATIONS}

The reported clinical sensitivity of RT-PCR is approximately $30-90 \%{ }^{4}$ Sensitivity of PCR assays depends on a number of factors including timing of specimen collection in relation to symptom onset, quality of specimen, specimen type, site of infection (upper vs lower respiratory tract), viral load, and gene targets of the assays. Repeated testing may be warranted in patients with clinical, radiological findings and epidemiological risk factors suggestive of COVID-19 infection. ${ }^{8,9}$

PCR testing is unable to differentiate between actual viral replication and non-viable, non-infectious, viral material. ${ }^{10} \mathrm{PCR}$ positivity may persist for more than 3 weeks in some cases. ${ }^{11}$ Serological diagnosis is not useful for the early detection of COVID-19. It may take 7 days or more after the onset of symptoms for patients to become antibody positive. Moreover, not all patients who are infected with SARS-CoV-2 develop detectable antibodies. ${ }^{12-14}$ However, serological diagnosis plays an important role in understanding the extent of COVID-19 spread in the community. The duration of immunity is not known, nor does the presence of antibodies predict protection from re-infection.

Sensitivity and specificity are particularly important in understanding the risk of false-negative testing and its subsequent consequences for both the patient and staff hence the need for a robust protocol to be in practice with minimal variability between centres. Even considering other viruses PCR has produced a wide range of results in terms of highly variable sensitivity, but early data from our colleagues in China suggested relatively poor sensitivity of initial RT-PCR tests. Even with sensitivity values as high as $90 \%$, the magnitude of risk from false-negative test results will be substantial as testing becomes more widespread and the prevalence of COVID-19 infection rises. ${ }^{15}$

There is emerging evidence that surgery can pose significant risks to certain groups of patients who test positive for SARS-CoV-2 in the pre or post-operative period. A multicentre, cohort study of 1128 patients with SARS-CoV-2 infection undergoing surgery in 235 hospitals in 24 countries found 30-day mortality of $23.8 \%{ }^{16}$ Pulmonary complications occurred in over $50 \%$ of patients with a 30 -day mortality of $38 \%$. Before the SARS-CoV-2 pandemic, high-quality, multinational observational studies established overall baseline rates of post-operative pulmonary complications of up to $10 \%$ and subsequent mortality of up to $3 \%$ after surgery. ${ }^{17-19}$

The increased risks of SARS-CoV-2 infection must always be weighed against the consequences of postponing surgery. Men aged 70 years or older, those with comorbidities (ASA grades 3-5), those undergoing cancer surgery, and those listed for emergency or major surgery are most likely to have adverse outcomes. ${ }^{16}$ Another study found a mortality rate of $20 \%$ in asymptomatic patients who tested positive for SARS-CoV-2 after surgery. ${ }^{20}$

The increased risk of contracting COVID-19 during or after surgery should be discussed with patients as part of the pre-operative discussion during the ongoing pandemic. To ensure the safety of patients and surgical healthcare professionals, there is a clear need for perioperative guidelines on patient selection, access to diagnostic tests, use of enhanced personal protective equipment, disinfection of theatres. Public Health England (PHE) recommend taking contact, droplet, and airborne protection as well as measures such as hand hygiene, use of surgical face masks, cohorting of staff and patients, use of negative pressure single rooms and theatres for COVID-19 positive patients, waste disposal, decontamination of equipment, and safe disposal or reuse of staff uniforms. ${ }^{21}$

As well as testing patients there will likely need to be an increase in testing staff regularly with recommendations for staff tests as regularly as day 1 , day 7 , and day 14 . This could reduce infection rates amongst health care workers by $64 \%$ and therefore reduce the potential risk of spread to patients. ${ }^{22}$ The Royal College of General Practitioners also supports regular testing of staff although this recommendation has not been actioned yet. ${ }^{23}$ 


\section{CONCLUSION}

Pre-operative COVID-19 testing is essential to minimize risks to both patients and staff. Testing strategies and the timing of testing continue to evolve and are based on guidance from public health bodies and the findings from local, national, and international practice, audits, and research studies. Testing of staff regularly will also be necessary to ensure transmission does not occur from staff to patients and between staff. ${ }^{23-25}$ However, regardless of COVID-19 status and patient risk factors it is evident from published studies that strict adherence to basic infectious disease protocols is vital. Continued social-distancing measures in hospitals, regular handwashing, surface disinfection, and finally, appropriate and adequate medical-grade personalized protective equipment for staff are also necessary as well as testing for COVID-19.

The following table summarizes recommendations for elective general anesthetic procedures by selected societies. The British Association of Urological Surgeons (BAUS) has not published specific guidance regarding pre-operative testing for COVID-19 although early in the pandemic BAUS published guidelines and protocols on triage of patients with different urological conditions during the pandemic. ${ }^{26}$

TABLE 1 COVID-19 Testing Protocol as Part of Pre-operative Assessment Protocols

\begin{tabular}{|c|c|c|}
\hline Institution & OTher Recommendations & Testing \\
\hline $\begin{array}{l}\text { UK intercollegiate guidance } \\
\text { Updated on } 13 / 5 / 2020 \\
\text { [https://www.rcsed.ac.uk/news- } \\
\text { public-affairs/news/2020/may/ } \\
\text { intercollegiate-guidelines-for-pre- } \\
\text { operative-covid-19-testing-for- } \\
\text { elective-cancer-surgery-update] }\end{array}$ & $\begin{array}{l}\text { Patients are asymptomatic for } 7 \text { days prior } \\
\text { to surgery, socially isolate for } 14 \text { days with } \\
\text { shielding } \\
\text { Where practical (if independent) self-isolate } \\
\text { for } 14 \text { days following discharge after surgery }\end{array}$ & $\begin{array}{l}\text { COVID-19 negative nasal and } \\
\text { oropharyngeal swabs } 72 \text { hours } \\
\text { before a procedure }\end{array}$ \\
\hline $\begin{array}{l}\text { American Society of } \\
\text { Anaesthiologists (ASA) } \\
\text { Updated on 18/5/2020 } \\
\text { [https://www.apsf.org/ } \\
\text { novel-coronavirus-covid- } \\
\text { 19-resource-center/ } \\
\text { preoperative-covid-testing- } \\
\text { examples-from-around-the-u-s/] }\end{array}$ & $\begin{array}{l}\text { All patients should be screened for symptoms } \\
\text { before presenting to the hospital. Patients } \\
\text { reporting symptoms should be referred for } \\
\text { additional evaluation. All other patients should } \\
\text { undergo nucleic acid amplification testing } \\
\text { (including PCR tests) before undergoing non- } \\
\text { emergent surgery. } \\
\text { Because false-negatives may occur with testing, } \\
\text { droplet precautions (surgical mask and eye } \\
\text { covering) should be used by OR staff for } \\
\text { operative cases. Before performing an aerosol- } \\
\text { generating procedure, health care providers } \\
\text { within the room should wear an N95 mask, eye } \\
\text { protection, gloves, and a gown. } \\
\text { If a patient tests positive for SARS-CoV-2, } \\
\text { elective surgical procedures should be delayed } \\
\text { until the patient is no longer infectious and } \\
\text { has demonstrated recovery from COVID-19. }\end{array}$ & $\begin{array}{l}2 \text { negative COVID-19 tests } \\
24 \text { hours apart in the last few } \\
\text { days before the scheduled } \\
\text { procedure }\end{array}$ \\
\hline
\end{tabular}


TABLE 1 (continued)

\begin{tabular}{|c|c|c|}
\hline $\begin{array}{l}\text { European Association of Urology } \\
\text { (EAU) } \\
\text { Updated on 1/7/2020 } \\
\text { [https://www. } \\
\text { europeanurology.com/article/ } \\
\text { S0302-2838(20)30324-9/fulltext] } \\
\text { [https://uroweb.org/wp-content/ } \\
\text { uploads/Gen-Rec-Surg-Proc- } \\
\text { April-14.pdf] }\end{array}$ & & $\begin{array}{l}\text { Patients with clinical symptoms } \\
\text { such as fever and respiratory } \\
\text { distress and/or with a travel } \\
\text { history to endemic areas } \\
\text { and previous contact with } \\
\text { COVID-19 patients should } \\
\text { all undergo pre-operative } \\
\text { COVID-19 test. In an } \\
\text { emergency, it is suggested } \\
\text { that these patients should be } \\
\text { handled as COVID-19-positive } \\
\text { patients to reduce the risk of } \\
\text { contagion for both patients and } \\
\text { health care workers. } \\
\text { Among patients without any } \\
\text { clinic symptoms, without } \\
\text { a travel history to endemic } \\
\text { areas, and previous contact } \\
\text { in the past } 2 \text { weeks with a } \\
\text { COVID-19-positive patient, } \\
\text { testing of elective patients } \\
\text { is recommended whenever } \\
\text { possible within } 48 \text { hours before } \\
\text { surgery in an outpatient clinic } \\
\text { setting. One may consider } \\
\text { starting with PCR testing and } \\
\text { withholding a chest CT only } \\
\text { if the PCR is positive for a } \\
\text { COVID-19 infection. However, } \\
\text { this might have severe logistical } \\
\text { implications (patients need to } \\
\text { visit the hospital repeatedly), } \\
\text { and joint testing of PCR and CT } \\
\text { may be a more desirable and } \\
\text { practical approach, depending } \\
\text { on the local situation. }\end{array}$ \\
\hline $\begin{array}{l}\text { National Institute for Health and } \\
\text { Care Excellence (NICE) } \\
\text { Updated on } 27 / 7 / 2020 \\
\text { [https://www.nice.org.uk/ } \\
\text { guidance/ng179] }\end{array}$ & $\begin{array}{l}\text { Follow comprehensive social-distancing and } \\
\text { hand-hygiene measures for } 14 \text { days before } \\
\text { admission (see government advice on social } \\
\text { distancing) } \\
\text { Self-isolate from the day of the test until } \\
\text { admission. }\end{array}$ & $\begin{array}{l}\text { Have a test for SARS-CoV-2 } \\
\text { from } 3 \text { days before admission, } \\
\text { and ensure the results are } \\
\text { available beforehand }\end{array}$ \\
\hline
\end{tabular}

$C T=$ computed tomography $P C R=$ polymerase chain reaction. 


\section{CONFLICTS OF INTEREST/ COMPETING INTERESTS / FUNDING}

Both authors declare that there are no conflicts of interest relevant to the topic to be disclosed. There was no funding involved to this work.

\section{REFERENCES}

1. World Health Organization. Coronavirus Disease (COVID-19) Pandemic. [Internet]. Available at: https:// www.who.int/emergencies/diseases/novel-coronavirus-2019

2. Peng L, Liu J, Xu W, et al. SARS-CoV-2 can be detected in urine, blood, anal swabs, and oropharyngeal swabs specimens [published online ahead of print, $2020 \mathrm{Apr}$ 24]. J Med Virol 2020;10.1002/jmv.25936. doi:10.1002/ jmv. 25936

3. Wang W, Xu Y, Gao R, et al. Detection of SARSCoV-2 in different types of clinical specimens [published online ahead of print, 2020 Mar 11]. JAMA 2020;323(18):1843-44. doi:10.1001/jama.2020.3786

4. World Health Organization. Shortage of Personal Protective Equipment Endangering Health Workers Worldwide. Geneva, Switzerland: World Health Organization; March 3, 2020.

5. Sethuraman N, Jeremiah SS, Ryo A. Interpreting diagnostic tests for SARS-CoV-2 [published online ahead of print, 2020 May 6]. JAMA 2020;10.1001/ jama.2020.8259. doi:10.1001/jama.2020.8259

6. Kim JM, Kim HM, Lee EJ, et al. Detection and isolation of SARS-CoV-2 in serum, urine, and stool specimens of COVID-19 Patients from the Republic of Korea. Osong Public Health Res Perspect 2020;11(3):112-17. doi:10.24171/j.phrp.2020.11.3.02

7. Lee TH, Lin RJ, Lin RTP et al for the National Centre for Infectious Diseases COVID-19 Outbreak Research Team. Testing for SARS-CoV-2: Can we stop at 2? Clinical Infectious Disease. Available at: https:// imsva91-ctp.trendmicro.com:443/wis/clicktime/v1/ query?url=https $\% 3 \mathrm{a} \% 2 \mathrm{f} \% 2 \mathrm{fdoi} .0 \mathrm{rg} \% 2 \mathrm{f} 10.1093 \% 2 \mathrm{fc}$ id\%2fciaa459\&umid=F3229CE5-A8D2-2F05-9E34C62374C9FB2C\&auth $=6$ e3fe59570831a3897168 49e93b5d483c90c3fe4-9cd09a7994162e519e23a0f1823bc1ee3709b224,

8. Green DA, Zucker J, Westblade LF, et al. Clinical performance of SARS-CoV-2 molecular tests. J Clin Microbiol 2020;58(8):e00995-20. Published 2020 Jul 23. doi:10.1128/JCM.00995-20
9. Zheng S, Fan J, Yu F et al. Viral persistence during recovery from COVID19. BMJ 2020;369:m1724.

10. Wölfel R, Corman VM, Guggemos W, et al. Virological assessment of hospitalized patients with COVID-2019. Nature 2020;581(7809):465-69. doi:10.1038/ s41586-020-2196-x

11. Guo L, Ren L, Yang S, et al. Profiling early humoral response to diagnose novel coronavirus disease (COVID-19). Clin Infect Dis 2020;71(15):778-85. doi:10.1093/cid/ciaa310

12. Zhao J, Yuan Q, Wang H, et al. Antibody responses to SARS-CoV-2 in patients of novel coronavirus disease 2019 [published online ahead of print, 2020 Mar 28]. Clin Infect Dis 2020;ciaa344. doi:10.1093/cid/ciaa344

13. Li Z, Yi Y, Luo X, et al. Development and clinical application of a rapid IgM-IgG combined antibody test for SARS-CoV-2 infection diagnosis [published online ahead of print, 2020 Feb 27]. J Med Virol 2020;10.1002/ jmv.25727. doi:10.1002/jmv.25727

14. Fang Y, Zhang H, Xie J, et al. Sensitivity of chest CT for COVID-19: comparison to RT-PCR. Radiology 2020;296(2):E115-E117. doi:10.1148/radiol.2020200432

15. COVIDSurg Collaborative. Mortality and pulmonary complications in patients undergoing surgery with perioperative SARS-CoV-2 infection: an international cohort study [published correction appears in Lancet. 2020 Jun 9]. Lancet 2020;396(10243):27-38. doi:10.1016/ S0140-6736(20)31182-X

16. Kirmeier E, Eriksson LI, Lewald H, et al. Post-anaesthesia Pulmonary Complications After Use of Muscle Relaxants (POPULAR): A Multicentre, Prospective Observational Study [published correction appears in Lancet Respir Med. 2018 Nov 6]. Lancet Respir Med 2019;7(2):129-40. doi:10.1016/S2213-2600(18)30294-7

17. Neto AS, da Costa LGV, Hemmes SNT, et al. The LAS VEGAS risk score for prediction of postoperative pulmonary complications: An observational study. Eur J Anaesthesiol 2018;35(9):691-701. doi:10.1097/ EJA.0000000000000845

18. Tu RH, Lin JX, Li P, et al. Prognostic significance of postoperative pneumonia after curative resection for patients with gastric cancer. Cancer Med 2017;6(12):2757-65. doi:10.1002/cam4.1163

19. Lei S, Jiang F, Su W, et al. Clinical characteristics and outcomes of patients undergoing surgeries during the incubation period of COVID-19 infection. EClinicalMedicine

J Endolum Endourol Vol 3(3):e29-e34; September 19, 2020.

This article is distributed under the terms of the Creative Commons Attribution-Non Commercial 4.0 International License. CBonatsos and Raza. 
2020;21:100331. Published 2020 Apr 5. doi:10.1016/j. eclinm.2020.100331

20. GOV.UK/Public Health England (PHE). [Internet] COVID-19. Available at at https:/www.gov.uk/coron avirus?gclid=EAIaIQobChMIrIK4t76q6gIVVoGyCh 2abg LkEAAYASAAEgKMWvD_BwE

21. Evans S, Agnew E, Vynnycky E, et al. The impact of testing and infection prevention and control strategies on within-hospital transmission dynamics of COVID-19 in English hospitals medRxiv 2020.05.12.20095562; doi: 10.1101/2020.05.12.20095562

22. No author. [Internet] Voluntary Weekly COVID Tests for all GPs 'Sensible', says RCGP. Pulse; September 7, 2020. Available at: http://www.pulsetoday.co.uk/news/ voluntary-weekly-covid-tests-for-all-gps-sensible-saysrcgp/20041450.article
23. Boyd C. [Internet] Former Health Secretary Jeremy Hunt calls for all NHS Staff to Be Tested for Coronavirus At Least Every WEEK from September to Prevent a Second Wave in Britain. Daily Mail; July 23, 2020. Available at: https://www.dailymail.co.uk/news/article-8552591/TestNHS-staff-regularly-Covid-19-Jeremy-Hunt-says.html 24. No author. [Internet] Regularly Test NHS Staff to Avoid Workers 'Silently' Passing on Virus - Experts. Express and Star; August 11, 2020. Available at: https:// www.expressandstar.com/news/uk-news/2020/08/11/ regularly-test-nhs-staff-to-avoid-workers-silentlypassing-on-virus-experts/

25. British Association of Urological Surgeons. [Internet] About Coronavirus \& COVID19. Available at: www. baus.org.uk/about/coronavirus_covid-19.aspx. 